\title{
Salesforce behavioural performance of accounts relationship managers (ARMS) in Uganda's commercial banks: A qualitative analysis
}

Received (in revised form): 2nd July 2009

\begin{abstract}
Joseph M. Ntayi
holds a PhD, MBA, Dip M, MCIM, International Postgraduate Diploma in Project Management and a Bachelor of Commerce. He has carried out a wide range of research in the areas of marketing, entrepreneurship and procurement in Uganda's Small and Medium Scale Enterprises (SMEs) and published papers in international refereed journals. His recent research work is in salesforce performance, work ethic, procurement practices, collaborative relationships, supply chain swiftness, moral disengagement and the social construction of procurement officer's deviant behaviours. He is currently researching on conflict and contract in the supply chains. Dr Ntayi has carried out a number of consultancy assignments for international agencies including the World Bank, SMEs and large companies in Uganda. He has edited a book on procurement trends in Uganda.
\end{abstract}

\section{John C. Munene}

is Professor of Organizational Psychology at Makerere University; he has researched in the area of culture for 10 years in England and Nigeria and is currently researching on the influence of social capital on the management of Universal Primary Education in Uganda. He has edited three books and published many articles on the concept of social capital and culture in international journals.

\section{Sarah Eyaa}

holds a Bachelor of Commerce and an MBA (MsM). She is Head, Department of Procurement and logistics Makerere University Business School. Her current research interests are in public procurement and transactions costs.

Correspondence:

Joseph M. Ntayi

Makerere University Business School, Plot M118 Port Bell Road, Nakawa, Uganda
ABSTRACT The purpose of this article is to examine the salesforce behavioural performance in commercial firms using a phenomenological approach. A sample of 75 accounts relationship managers (ARMS) from 15 commercial banks was selected. Results reveal that background factors provided vicarious reinforcement behaviours while vicarious punishment reinforced social skills that were necessary for selling bank services. Social network ties were particularly necessary in increasing salesforce behavioural performance while poor family background coupled with lack of career planning, limited professional sales presentation impacted negatively on the performance of the sales career. Serendipity, development networks, social dyadic interactions with customers and key stakeholders were found necessary in generating, building and retaining customers. This is because customers' lives depend on how they are tied into the larger web of social connections. We therefore recommend banks to hire ARMS based 
on vicarious learning, family background, social networking skills and development networks if they want to improve performance. Journal of Retail \& Leisure Property (2010) 9, 5-23. doi:10.1057/rlp.2009.19

Keywords: vicarious learning; development networks; serendipity; sales career; social networking

\section{BACKGROUND}

The context in which salespeople do their jobs has been observed to have a high influence on their selling effectiveness. Research has revealed that salespeople who are supported by their social structures draw career support that is necessary for the performance of the sales job. This is supported by Forret and Dougherty (2004), who aver that efforts to grow and retain associations have the potential to provide significant career information and assistance. As Bandura (1977) has noted, a salesperson is an enquiring organism that develops by constructing personal explanations based on information and accumulated experience. The selling job requires a salesperson to construct explanations for customer behaviours, sales presentations and closing a sale. Consistent with Bandura (1977), the salesperson goes through modelled and cognitive script seeking to master their daily selling experience and to design and implement mechanisms of interaction with bank customers. The construction process is a cognitive activity involving interpretation of the selling environment, anticipation of events, knowledge structures (schemata) (Szymanski and Churchill, 1990) and dissemination of information during the sales process to influence both outcome and behaviour performance. Salespeople will take actions based more on primary drivers like ability, motivation and context. Therefore transforming sales performance requires the sales professionals to ably enhance salesforce knowledge and skills, on offerings, job and customer, be motivated to achieve goals, be aware of the metrics (how performance is measured), and engage in a feed back process as well as understanding the reward systems. A salesperson is a scientist metaphor who uses schemata as a fundamental tool in the learning process (Kelly, 1955). Of critical importance is the survival and development of the salesperson garnered vicariously by observing behaviours (Eyal and Rubin, 2003).

The aetiology of dynamic or flaccid salesperson's behaviours may be built based on homophily, identification and parasocial interaction (Eyal and Rubin, 2003), all of which derive from the social network theory. Higgins and Kram (2001) drawing from the social network theory have attempted to study a network of 'developers' that offer varying degrees of psychosocial support and role modelling. This is consistent with prior research that considers individuals as navigating a turbulent career environment, forcing them to draw from multiple sources of developmental support (Higgins and Kram, 2001). It has already been documented that changes in organizations (for example downsizing, flattening of hierarchies and the pace of change) require individuals to 
regularly learn new knowledge, skills and competencies to be able to perform effectively in rapidly changing and team-based environments (Arthur and Rousseau, 1996). Although researchers have attempted to study developmental relationships, the connection between vicarious learning, developmental networks and salesforce behavioural performance remains relatively unexplored. Yet individuals require self-awareness and adaptability as essential 'meta-competencies' in their job performance. Additionally, despite the increasing amount of research on the predictors of salesforce performance, there are only a few studies from sub-Saharan Africa to draw upon. Most of the literature is based upon anecdotal evidence and hypothetical speculation (Ntayi, 2005). Kamuhanda (2001) and Ntayi (2005) have revealed that overall, bank salespeople in Uganda who lack knowledge, withhold vital information, fail to manage customer interactions and react by occasional forced or voluntary resignation thereby failing to contribute to organizational performance. The purpose of this article is to cover this deficiency in the literature by using vicarious learning, serendipity and development networks to predict salesforce behavioural performance in Uganda using a phenomenological approach.

\section{DEVELOPMENT OF THE THEORETICAL FRAMEWORK AND LITERATURE REVIEW}

\section{Theoretical and conceptual background}

The constructive alternativism theory (Kelly, 1955) of individual and group psychological and social processes, based on positive scientific position, was found relevant for this study. This theory, also referred to as Personal Construct Psychology has attracted widespread attention and application in management, education and clinical psychology (Shaw, 1981). Personal Construct Psychology theory provides a foundation to several models of human learning namely Cognitive Development Model and the Social Learning Model and the Social Cognitive Career Theory developed by Lent et al (1996). Personal Construct Psychology theory is a personality theory, which has received relatively little attention in both marketing and sales literature. This theory provides a framework for the prediction of salesforce outcome and behavioural performance (Plank and Reid, 1994). Kelly (1955) sought to understand human personality by examining individual's own interpretations of themselves and their social world, which is a fundamental activity of the selling job. The term personal construct was used to refer to the dimensions people use in their attempts to interpret the people and events in their lives. As observed by Swinney et al (2000), people's behaviour is a function of learning. Our experiences and interactions continually influence our activities and behaviours (Rotter, 1966). Behaviours occur as a result of complex interplay between inner processes and environmental influences (Bandura, 1977; Lent et al, 1996).

Kelly's theory (1955) emphasizes the process of cognition as the primary factor in the formation of peoples' behaviours. This theory is founded on the philosophical position of constructive alternatives, the assumption that any one event is open to a variety of interpretations. 
Individuals create their own ways of understanding events around them using constructs or patterns that make the world meaningful to them. In this way, people act as scientists and as such develop constructs that are similar to postulates, propositions and or hypothesis. These hypotheses are tested during the selling encounter. If they are confirmed, ARMS tend to hold onto them, otherwise they are revised in light of the experimental results. It is suggested that these results are responsible for the development of selling behavioural patterns. Kelly (1955) suggests that the way in which individuals predict future happenings is crucial to their behaviour. The future, rather than the past, is the primary impetus of behaviour. It is suggested that the same life events are viewed somehow different by different people because they are perceived through unique individual constructs, which are analogous to different coloured glasses (Kelly, 1973). Construing another person's construct is important in the selling profession, which thrives on interactions with the people and with the environment on the continuous basis. We construe constructs, which are more personally meaningful. This is typical in the selling job as a sale is made, not over the counter or desk, but in the mind of the buyer. The seller's every word and every gesture should have an objective of making the right impressions on the mind of the prospect. As selling is a social encounter. Kelly's (1955), sociality corollary provides an insight into our personalities arising out of social interactions, which are at the heart of selling and marketing.

This basic postulate is particularly relevant to salesforce behavioural performance. Sales managers require knowledge of the salesperson's construct system indicating how fully or accurately the sales interaction situation has been interpreted. Leong et al (1990) suggest that confidence in better-developed knowledge system leads to higher salesforce performance. The ability to adapt to selling situations resulting in superior performance despite pressure inherent in the sales job is a result of schemata or knowledge structures (Sujan et al, 1988; Leong et al, 1990; Szymanski and Churchill, 1990). Although attempts have been made to predict salesforce performance, few studies from developing countries have utilized a qualitative approach.

\section{Vicarious learning and salesforce behavioural performance}

Vicarious learning also known as observational learning is associated with Bandura's (1972) social learning theory. Vicarious learning occurs when salespeople decide, after observing the performances of other salespeople, what types of events will be effective or non-effective for their own performance of a task. This is consistent with Kelly's conceptualization in which he asserts that 'A person's processes are psychologically channelized by the way in which he anticipates events' (Kelly, 1955, p. 46). He saw all people as scientists engaged in anticipating the world and states that 'A person anticipates events by construing their replications' (Kelly, 1955, p. 50). Kelly's construction was based on constructive alternativism, which support individuals to develop alternative constructs systems through which to construe life events. Constructive alternativism theory creates confidence and positive 
attributions leading to positive selling behaviour if the salespeople believe that they are worth imitating, otherwise the selling career will be abandoned. According to social cognitive theory, Bandura's (1997) vicarious experiences can accelerate learning through the performance of every desirable behaviour. Such observations are important because they help the salesperson make sense of a sales interaction and plan appropriate selling behaviour as the sales encounter unfolds. Although sales situations vary from one encounter to another, salespeople have to be adept and expressive in adapting to these situations (Weitz et al, 1986) by construing their replications (Kelly, 1955). Learning curves are vicariously influenced based on their observation, discussion and inferences drawn from the experiences of others (Baum and Paul, 1998). Research has also demonstrated that vicarious team learning behaviour is positively associated with team performance. From the above discussion we can propose that,

Proposition 1: Vicarious learning leads to positive attributions resulting into appropriate selling process and improved salesforce behavioural performance.

\section{Vicarious learning and serendipity}

Serendipity, which is defined as finding unexpectedly something valuable that was not sought for (Diaz de Chumaceiro, 1995), continues to be a focus of inquiry in management literature and individual performance (Betsworth and Hausen, 1996). The concept of serendipity owes its origin from the works of Horace Walpole in a letter to Sir Horace Mann on 28 January 1954 (Remer, 1965, p. 20): 'This discovery is almost of a kind which I call serendipity, a very expressive word ... I once read a silly fairly tale called the Princess of Serendipity ... as their highness travelled, they were always making discoveries, by accidents and sagacity of things which they were not in quest of ...' '. Serendipity has been considered in the literature to exert a dramatic influence over our lives (Kathleen et al, 1999). Most people agree that serendipity (chance, luck) has played an important part in their job performance (Betsworth and Hansen, 1996). It has the power to transform the improbable into the possible - to make the difference between life and death, reward and ruin, happiness and despair (Wiseman, 2003). This is consistent with Cobbledick (1996), who revealed serendipity was an important source of artistic stimulation. Cory (1999) contends that serendipity plays an important role in revealing hidden connections or 'hidden analogies', enabling creative connections to develop. In the study of the categorization of serendipitous career development events, Betsworth and Hansen (1996), found that two-thirds of the participants believed that the performance of their jobs were significantly influenced by chance events. Authors identified the most frequently cited categories of serendipitous events significant to job performance as professional or personal connections, unexpected advancement, right place/right time, among many others. This is consistent with Dexter (1977), who contends that luck is deemed 
apparent in being in the right/wrong place at the right/wrong time. We therefore propose that

Proposition 2: Serendipity results into improved salesforce behavioural performance.

\section{Development networks and salesforce behavioural performance}

Stewart (1998) asserts that the burgeoning volume of literature on the subject of sales and marketing strongly promotes a need for skills and confidence required in the development of longer-term relationships with customers. These relationships are a result of the development of development networks. Development networks are defined as concurrent relationships that are specifically developmental in nature (Molloy, 2005, p. 538). One major activity that characterizes development networks is mentoring. Drawing from career literature, mentoring is deemed to occur if mentors take an active interest in advancing the salesperson's career by providing developmental assistance (Higgins and Kram, 2001). Examples of potential developers and/or mentors may include peers, individuals from other organizations, former job incumbents or retirees and lecturers. Adler and Kwon (2002) conceptualize development networks as a component of social capital. Development networks are known for providing access to information, career advice, social support, business leads, resources, collaboration and professional support. An individual's ability to engage in development network was the strongest predictor of job performance (Adler and Kwon, 2002). From this we propose

Proposition 3: Development networks and salesforce performance are positively related.

The effect of this relationship is important because salespeople who use development networks are likely to be embedded in a social web that results in the development of cognitive skills. Correspondingly, salespeople with little confidence are more likely to believe (even when this is incorrect) they have been assigned a difficult sales job. Although previous findings have shown positive relationships between self-efficacy and work-related accomplishments (for example Gist and Mitchell, 1992), studies providing empirical validation for the link between vicarious learning and a salesperson's development networks of mentoring (Marakas, 1998) are sparse. From the above review of literature we derive our conceptual model as presented in Figure 1.

\section{METHODOLOGY}

\section{Research design}

This study adopted the nomothetic approach of qualitative inquiry because of its ability in describing processes of vicarious learning, locus 


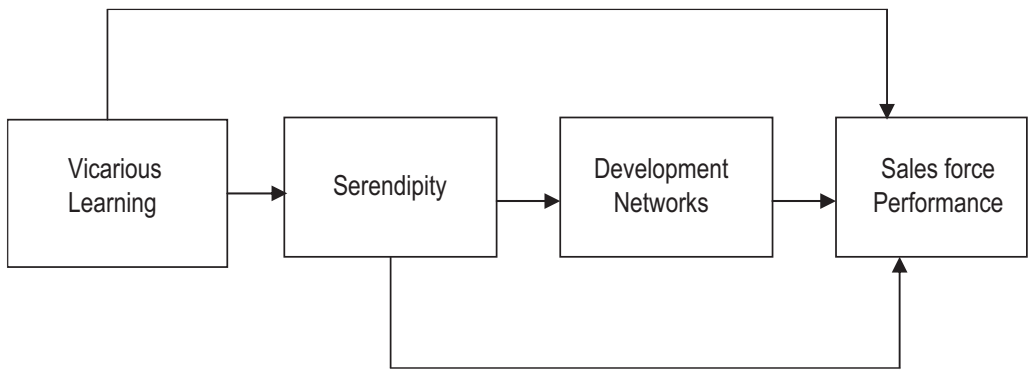

Figure I: Conceptual relationship between predictors of salesforce behavioural performance.

of control, serendipity, development networks and how these processes relate with salesforce behavioural performance. The qualitative research design was associated with interpretative approaches from the informants' emic point of view, rather than etically measuring discrete, observable behaviour (Frechtling and Sharp, 1997). The corresponding results of the subjective inquiry are presented in vignettes, case and graphical displays in the results section of this article.

\section{Sample size and sampling design}

Five accounts relationship managers (ARMS) were selected from each of the 15 commercial banks giving a sample of 75 ARMS (40 men and 35 women). This sample comprised of staff interacting with customers on a fairly long-term basis, composed of the prestige or high network banking, corporate division and international division. The ages of the participants ranged from 23 to 50 years. The biggest proportion of salespeople was in the age range of 25-30 years, constituting 43 per cent of the sampled respondents. This was followed by the age range of 31-35 that constituted 18.7 per cent. The age range of 36-40 years constituted 17.5 per cent of the bank salespeople. The age categories of 25-30 years and 31-35 years had the highest number of salespeople with both undergraduate and postgraduate degrees, accounting for 31.5 per cent and 13.4 per cent, respectively, of the total salesforce employed in the banking sector. This was followed by diploma holders with 11.0 per cent for 25-30 years of age. Furthermore, the results show that the majority of the sampled salespeople had undergraduate university degrees (61.1 per cent) followed by diplomas ( 21.6 per cent) for 36 years of age and below.

\section{Measurements}

Vicarious learning measures were derived from Ellen et al (1991) and Schwarzer (1994). Serendipity scales were adapted and modified from Kathleen et al (1999), while measures for development networks were derived from scholarly works of Molloy (2005) and Adler and Kwon (2002). Salesforce behaviour performance was measured by the sales manager's summary assessment of the salespeople in terms of technical knowledge, adaptive selling, teamwork, sales presentation, sales planning and sales support. All the scales were based on previously published studies (for example Behrman and Perreault, 1982; Spiro and Weitz, 1990). 


\section{Questionnaire development}

The in-depth qualitative data collection approach adopted in this article took the nomothetic or variable-centred approach to help understand the relationships between the study constructs of all salespeople in the banking industry. The unstructured 'raw' data were stored in form of tapes, field notes, memoirs and transcripts. Consequently, all the raw data were organized in memoirs before the development of causal networks. The transcribed data were carefully read line by line, and divided into meaningful analytical units (that is, data segmentation). Meaningful segments were coded. Each interview was assigned a number or code. Interviewees were given pseudonyms. During coding, a list of all the codes that were developed and used in the research study was kept. Codes were reapplied to new segments of data each time an appropriate segment was encountered. Special care was taken for intra-coder reliability. Further inductive codes were developed by directly examining the data. We continued to refine and revise the codes. This was followed by searching for relationships in the data, as there were no 'quick fix' techniques in qualitative analysis. A secure file linking pseudonyms and code numbers to the original informants was developed and kept confidential.

\section{Validity, reliability and analysis}

This study tried to follow research procedures that ensure repricability of results or observations by using multiple raters or coders and carefully trained interviewers. Qualitative data were collected by three people, the principal investigator and two experienced research assistants. Initially there was wide variation of responses from the two interviewers given their informal conversational nature. This problem had earlier been observed by Fontana and Frey (1998). The desire to maintain consistence led to the development of an established interviewing strategy and comparing field notes at the end of every field working day. Interviewers were further considerate of their non-verbal behaviours including the attire to wear when meeting respondents. In a bid to increase consistency of results and avoid errors cited by Kirk and Miller (1986), the researcher used three people at the data collection stage and four people at the data analysis stage. This assisted in comparing notes for confirmation (LeCompte and Goetz, 1982). Check-coding was further used to assess reliability at the data analysis stage. Miles and Huberman (1994) have described 'check-coding' as a process by which two people separately code the same data, then come together to compare codes. This was intermittently done until reliability reached satisfactory levels with intercoder agreement of 93 per cent. Variety in data was achieved by collecting data from different banks at a variety of times (for example during a 'busy and less busy seasons'). Similar patterns seemed to occur during these different seasons. When presenting qualitative findings, this study also drew from published literature to validate findings as recommended by Strauss and Corbin (1990). Data analysis tended to be a cyclical process (interim) using Nvivo software. This continued until the research problem was understood. Throughout the entire process of qualitative data analysis it was deemed fit to engage in memoing (that is, 
recording reflective notes about what is learned from the data). These memos were included as additional data to be analysed. Analytical methods included: text coding, Vignettes, memoirs, intuition, graphical displays and causal networks.

\section{PRESENTATION OF RESULTS/FINDINGS}

\section{Background factors, vicarious reinforcement and vicarious punishment}

Background factors provided vicarious reinforcement behaviours (response facilitation) and vicarious punishment (response inhibition), which reinforced social skills necessary for the selling career thereby promoting salesforce behavioural performance, supporting Proposition 1. Respondents indicated that family and friends - especially parents, ones up-bringing, personal experiences, ambition and exposure to selling career information was a characteristic of ARMS life and accounted for the ARMS career choice and the development of selling skills (see Figure 2). This study reveals that ARMS who received plenty of positive attention from parents during their infancy had greater chances of developing their careers in the parents' area of profession and exhibited improved behavioural performance. For females, maternal employment and the need to take care of the young ones was related to the ARMS choice of their banking career. Mothers served as role models, while fathers were a source of encouragement (see Figure 2). The following representative case display confirms the above observation 'I am lucky to have been a first born of a family of six (6) children. I grew up under the care of my parents who loved me so much. Both dad and mum were very strict and tolerated no nonsense. My parents were both bankers and very religious. They often practiced the Roman Catholic Faith. ... I grew up

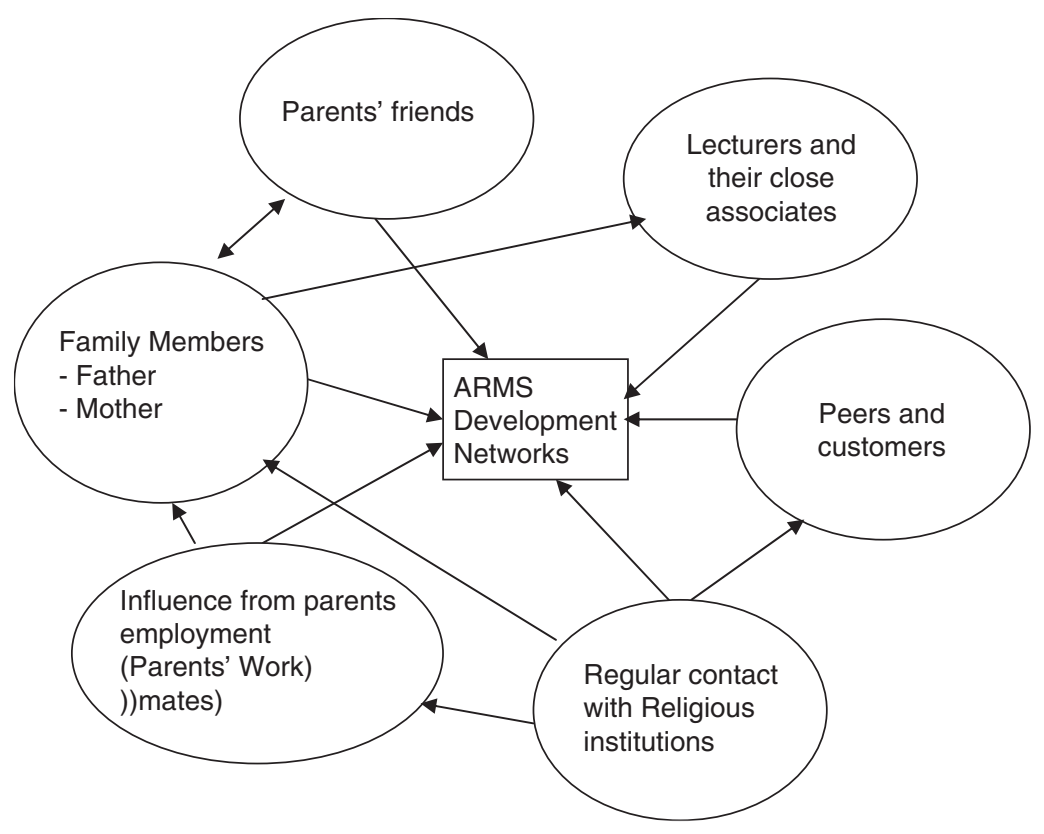

Figure 2: Accounts relationship managers' (ARMS) development networks. 
morally upright, humble and very reserved. As a child I admired my parents' profession. My dad used to refer to me as "Jane the banker", a title that motivated me to work hard and attain. I went through strict parental training. I often interacted with my parents work mates and friends who always looked satisfied with their banking profession. I developed a belief that only hard working people like my parents had a place in the successful world. ... I am very hardworking and that is why I am the only female ARM among the top five members of staff that have served in the bank for a long time without loosing a job despite the current job insecurity in the banking industry. But above all I am very loyal to my employers. Without loyalty one has no place, even when you can move mountains ... '(Case 18). The ideas presented in the above case displays were attested by 52 per cent of the sampled respondents.

From the above case and the summary presented in Figure 2, we contend that family background provided attention, interest, inspiration and physical resources that acted as basic inputs in career decision making and aided behavioural performance of ARMS. These resources included family training, strict religious upbringing, networking and discussions with parents, materials to aid learning and other social support from parents' relative's friends and acquaintees. Figure 2 reveals that social connections developed by ARMS through family led to the development of networks that influenced their career choice and interest in the banking profession. These social networks, which are an extension of family social relations, ones lecturers and customers, proved to be useful in providing filtered customer information, planning, developing and locating large account customers through referrals, when the ARMS were working with commercial banks. The following case from one of the bank customer interviewed supports the finding 'As the saying goes one good turn deserve another. I try very much to help the bank because of the assistance it gives me. It is not that I bring them customers; I have introduced a number of people to open up bank accounts who later become bank customers through borrowing ...'(Case 26).

Customer referrals have been contributory to the development of vicarious learning. The ARMS' selling confidence was developed as a result of the influence from role models within the social networks. Cohesive contacts between ARMS and social networks resulted in making the right selling decision at the right time, with the right method of presentation and follow-up. ARMS with the contact network(s) exercise control over the more rewarding opportunities. They monitor information and move information faster. The following response from 'Sarah' confirms the facts presented. 'I usually generate a simple list of actual and potential customers through social networks. This list is developed with the assistance of the people most close to me (customers, relatives and friends). I have wined and dined them, entertained them and phoned them up (using bank resources) ...' .

\section{Development networks and salesforce behavioural performance}

Respondents attributed their good performance to utilizing connections through friends, family members and acquaintances that were a source of 
inspiration and support, thereby positively affecting their behavioural performance. Through these connections, trustworthy relationships were developed that generated career and sales information, sales referrals and advice. Through observations and associations with peers who worked with banks, ARMS were persuaded to join the banking career. The following case supports the above finding - 'Enoch, an acquaintance that worked with the bank, informed me of a job that fell vacant in a new project (computer system inter-bank linkages). I knew that my dream had come true, since I had always admired and respected people working with banks. I followed up this job opening closely through relatives and friends. It all worked out well very fast and I joined the Bank'. Conversely, poor family background coupled with lack of career planning, limited professional sales presentation impacted negatively on the sales career, supporting Proposition 1. Although many ARMS considered working with the banks prestigious, others considered the ARMS job inferior. This made them shift focus from the selling job to the prestige associated with the bank. This has not only diminished the behavioural performance against which they are evaluated but also led to a declining interest to acquire new customers. Some ARMS who enjoy the selling career have used the presence of powerful social networks, influential and supportive customers as a benchmark for their behavioural performance.

\section{Social dyadic interactions, serendipity and salesforce performance}

Results reveal that serendipity and development networks resulted into improved behavioural performance, thus supporting Propositions 2 and 3. Social dyadic interactions with customers and other stakeholders were necessary in generating, building and retaining customers. This is because customer's lives depend on how they are tied into the larger web of social connections. ARMS and customers develop friendship that goes beyond the official business. This is interpreted by customers to mean that banks care and are very close to them. According to 'Nyakat', a bank customer, for example, whenever the bank organizes end of year parties or launches a new product, he is invited for the function. This is attested in the following vignette. ' ... our firm usually honours the bank invitation to attend their functions. We also never forget sending season's greetings, calendars or newsletters. Recently at a new product launch, I met a sweater producer from Kenya and we struck a business deal for his firm to supply our firm. The bank has agreed to finance the deal. Personal friendship is good for relationship building. We are usually invited by our bankers to their private functions and we also occasionally invite them too. This has brought us close and the benefit of this association is evident in the way we access loans from the bank ... . Seeing things in each others perspective is possible to some extent. For example when we are unable to meet commitments, we explain this to the bank and they do understand our shortcomings. Similarly, when we want finance and the bank says at present they are unable to extend the loan because of some constraints, we do understand them. But unless explained we do not 
understand their perspective well and we believe they do not understand ours either.'

The above vignette reveals that the nature and frequency of social interactions are essential for building customer networks thereby improving businesses of customers. Through such interactions, customers were linked to business partners with mutual interest. This led to the development of meaningful bonds, which eventually translated into increased social interactions, closeness, friendship and satisfaction as shown in Figure 3. Social bonds assisted in removing doubt, created trust and formed close relationship between parties. Social interactions are also necessary in building relationships. There is need to relate with customers and develop friendship that goes beyond the official business. This includes attending birthday functions, to mention but one. In such a relationship it is important to be transparent and open to each other. You need to understand one another and this is only possible when you open up to each other. Kiw asserts that - Recently when I wanted to buy property adjacent to my business I first invited the bank ARMS to appreciate what I intended to do with the loan. He came along with the bank's valuer. They inspected the property and valued it at Shs. 90 million. I had only requested the bank for Shs. 45 million for the property. Because I was open to the bank on how I would use the money, I had no problem acquiring the loan.

Additionally, commercial banks and bank customers have to keep their promises. If the borrower needs some support and the bank promises to support, it must do so at the right time. Similarly, the borrowers must keep their promise to the bank. If an installment is due it must be met. If for any reason you are unable to meet the installment, you need to approach the bank with proper explanation for rescheduling the loan repayment and a definite promise to pay in future. Nkay revealed that in December 2003, he had this problem - 'I had reserved Shs. 15 million Uganda Shillings on my account for the December installment on my loan. But the school lacked money to pay teachers' salary for December. I explained to the credit manager the need to pay the teachers salary and postpone the repayment till end of January 2004 when parents would start paying school fees. He was able to understand this. So, Shs. 8 million was taken as part installment and I used Shs. 7 million to pay the teachers. At the end of January I was able to pay the balance of the installment. This is the kind of promise I am talking about'.

Despite their training and professional knowledge, ARMS attributed their performance partly to serendipity (for details see Figure 3), supporting Proposition 2. Serendipitous events enabled ARMS to access and recruit profitable customers. In these cases something more than chance was implied. Serendipity did not arise from random accidents but from circumstances brought about by unconscious motives, which led ultimately to the serendipitous events. Analysis of qualitative data includes terms, which indicated a level of 'unplanned surprises' during selling. Interviewees talked of chance, accident and 'just happened to' meet a potential customer who acted as a sales lead to other profitable customers. This is supported by the following quotations. ' ... When I was doing my routine check up, I met a prospective customer in the 


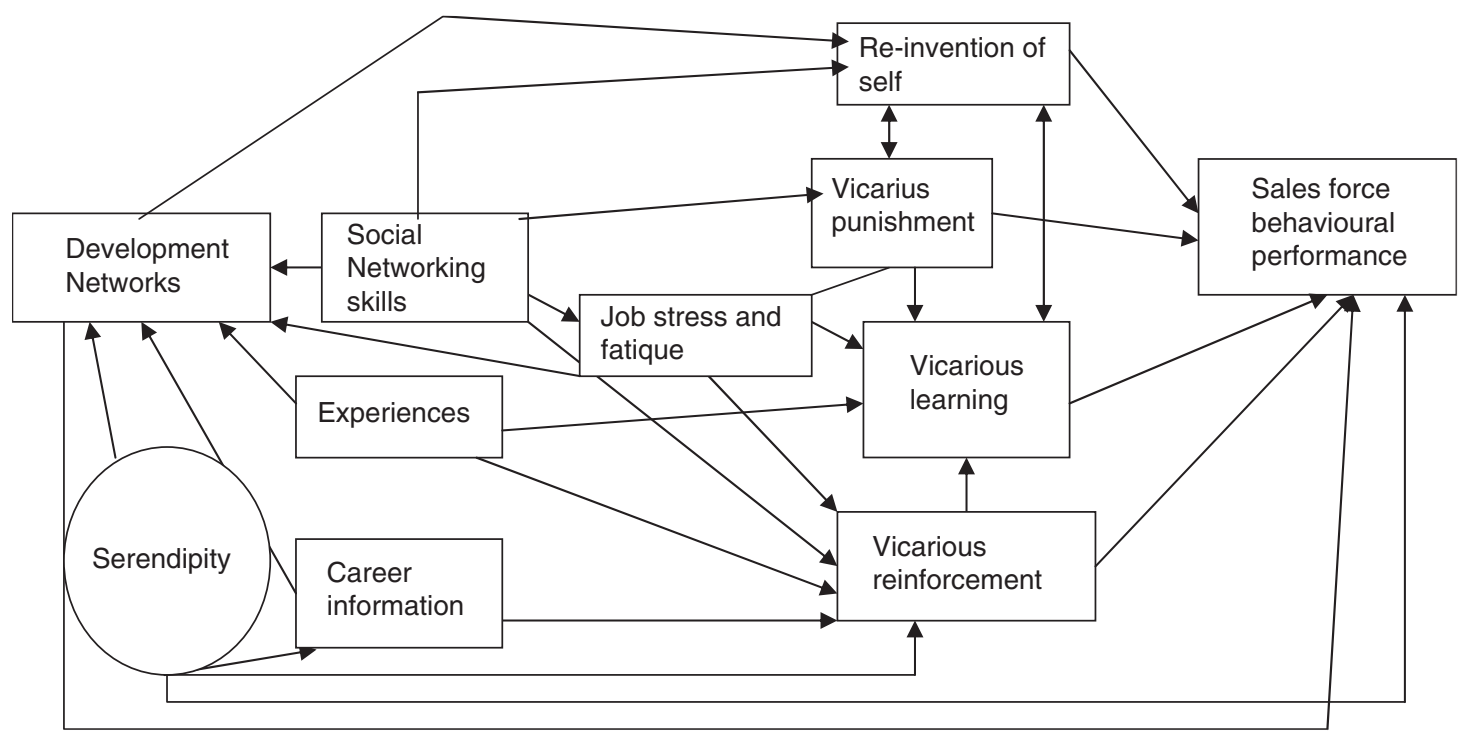

Figure 3: Causal network for development networks, vicarious learning, serendipity and salesforce behavioural performance.

client's office who had gone there on his own business, who got interested in our bank and its financial products and services. He bought the bank products and later introduced us to other profitable customers. $\mathrm{He}$ is one of my best large account customers; I don't want to loose him because he always brings us revenue and profitable accounts' (Case 14). By contrast, chance encounters led to new unanticipated outcomes. Interviewees revealed the fact that serendipity sometimes opened their eyes to psychological strengths (psychofortology) and to a whole set of selling opportunities. Further some ARMS spoke of making their own luck via hard work and persistence. ARMS did not discount the role serendipity had played in their career path. Serendipitous events expressed in terms of ones' family background, working for a caring organization with a supportive work environment, having a competent and caring supervisor were key in improving behavioural performance. Whereas some ARMS were lucky to have had strict career-focused parents, others found luck in accidental acquaintances met during sports and selling missions. For example, female ARMS had this to say "was not the best qualified for this sales Job but my sporting skills enabled me to get social contacts for the bank job' (Case 2).

\section{DISCUSSION OF FINDINGS}

\section{Background factors, social dyadic interactions, development networks and salesforce performance}

The findings presented above shed light on a number of interesting issues and lend empirical support to the propositions that were developed for this study. Results reveal a consistent effect of background factors on salesforce behavioural performance. ARMS reported career events of familial factors, education, religion, age, social dyadic interactions and networks as important antecedents to salesforce behavioural performance. 
Montgomery (1993) and Schneider (1994) have revealed that background factors provide common ground, which help people to relate well to each other. Almost all of our interviews highlighted the importance of having things in common with another person as an important step of building relationships and improve performance. For example one ARMS indicated - 'it was after learning that we had a lot in common with the newly recruited ARMS that I volunteered to assist in all ways humanly possible ...' '. The interview results revealed that they were Moslems, in the same age range, had studied together at college and had at one time lost a job. This background was the basis for their association. Montgomery (1993) supports the above finding by asserting that common background provides a basis for developing relationships and connections. Connections create a belief that each person has a level of concern for the other. Kakabadse (1999) has suggested that time and experience in terms of age result in performance. Further, King et al (1998) attest that training and education strengthens characteristics of performing individuals like resourcefulness and problem solving.

Consistent with the findings of this study, extant literature reveals that good performing people are sociable (Gordon, 1995). Sociability improves cohesion, promotes behavioural performance, collaborative effort and career growth, encourages sharing of tacit knowledge (that which is undocumented) and leads to performance in a supportive social environment. ARMS' development of social resources is a necessity for the development of vicarious learning over selling situations. ARMS enjoyed the social aspects of their work, the social networks, and the companionship with fellow workers and customers, thereby benefiting from their communications. Benefits of work such as communication with other people and human contact (Chanley et al, 2000) are a necessity for interactive jobs like selling. Rosenblatt et al (1985) assert that social networks make social resources available to newcomers in a career. Networks are significant contributors to ARMS innovations. Networks have also been found to promote salesforce behavioural performance. Empirical research concurs that when used entrepreneurially, personal contact networks can produce marketing benefits by providing reliable information about careers, customers and competitors (Shaw et al, 1998). Further comparative analysis and synthesis of qualitative data collected reveal that networks promote salespersons' entrepreneurial behaviour, a characteristic of better performing salespeople. This is consistent with Lumpkin and Dess (1996), who assert that the ambition level and the scope of entrepreneurial action are determined by salesforce behavioural performance.

\section{Vicarious learning and salesforce performance}

Findings revealed that enactive vicarious learning was essential in promoting performance. Bandura $(1986,1997)$ has revealed that vicarious learning provides the most authentic evidence of information about success in a specific domain. Salespeople referred to information processed cognitively and the aid they got from their networks that helped them to form positive appraisals of their capabilities. For example 
Wand (Case 10) revealed that he had done a lot of selling work in the past, drawing from the resources and support of networks and connections that people do not easily have access to. With this support and wealth of experience achieved, he managed to recruit many new customers. He can now deal with bank customers according to their needs. Currently, he is good at selling, hard working and perseverant. He does not easily give up. What keeps him going is his desire to excel. He has always been recognized as a hardworking employee of the bank and awarded a certificate of excellence. He is encouraged to work hard because of his performance.

Additionally, Agnes, a 33-year-old corporate accounts officer, who had previously worked in Hotel Equatorial (U) Ltd, had a banking experience of 5 years. She decided to leave the hotel where she was working in accounts department and joined the bank because of the promising selling career. She did not discount the role talent and experience played in performing the selling career, but she gave credit to the family and social support. Females valued social and verbal persuasion they received from others. They experienced vicarious learning from their family members and peers. Positive persuasions worked to encourage and empower while negative persuasions worked to weaken self-beliefs. The following case supports this. ' ... when I was hired as an ARM in this bank, workmates tended to avoid me. This avoidance sent negative messages to me and affected my confidence negatively, although the bank encouraged every bank employee to work as a team. There are some people in the department that are both close and distant to me. Instead of concentrating on their work, some people in the bank waste time gossiping about me. These are the same people who gripe at my back looking for favours from their bosses ... '. This case confirms Zeldin and Pajares (2000), who suggested that females form their vicarious learning belief as a result of their relational experiences. Gilligan (1977) argued that women use the relationships in their lives as a foundation on which to ground their behaviour.

\section{IMPLICATIONS}

\section{Theoretical implications}

The first notable theoretical implication of this study is its contribution to the ongoing salesforce performance debate. From the foregoing we assert that in order to understand salesforce performance, managers must shift from their espoused traditional expectancy motivation model (Churchill et al, 1985) and the adaptive models currently in use and introduce a cognitive constructivist personality trait as a potential framework for integrating personality dimensions into salesforce performance research. Previous researchers have failed to acknowledge that some salespeople fail to perform even when they are in possession of the requisite selling knowledge. For example, Goleman (1998) has revealed that salespeople, who possessed technical skills and cognitive abilities, were unable to perform in the first 2 months of their recruitment owing to lack of confidence. The study further show that 50 per cent of the salespeople 
in the United States quit within 2 months after recruitment and 65 per cent left in 2 years, mostly because they lacked self-confidence. This finding is further corroborated by Kamuhanda (2001), who asserts that overall, bank salespeople in Uganda who lacked confidence in themselves attributed failure to factors beyond their control, withheld vital information, failed to manage customer interactions and reacted by occasional forced or voluntary resignation. The second theoretical implication relates to the importance attached to the vicarious learning. Empirical evidence has suggested that vicarious learning affect salesforce performance.

\section{Methodological implications}

One major methodological implication is the role of multimethods approach in predicting salesforce performance. This study attempted to build upon prior work in the area of salesforce performance by using qualitative data to predict salesforce performance. From the afore cited practice, the move has been made towards methodological coexistence suggesting that qualitative and quantitative approaches to sales and marketing inquiry should not be taken as mutually exclusive and competing paradigms, but rather as approaches that have potential to complement each other. Future researchers can now build upon our work by integrating qualitative and quantitative research methodologies. This, however, requires charting taxonomies for studies combining quantitative and qualitative research in different ways. This once done shall provide terminological and conceptual clarity and coherence (Tashakkori and Teddlie, 1998). Support for the multimethod and mixed designs is derived from extant literature that reveals that mixed designs remains largely unstudied (Newman and Benz, 1998; Tashakkori and Teddlie, 1998).

\section{Managerial and policy implications}

The first major managerial implication concerns the recruitment of ARMS based on the ARMS vicarious learning, social networking skills and development networks as these significantly affect salesforce performance. Bank managers may want to hire ARMS who are resourceful and have social skills and a web of social connections for positions that require moderate to constant interaction with customers. However, before organizations begin selecting employees on the basis of these personality characteristics, more research is required, especially because these characteristics were not studied in a selection context. Further, for the salespeople who are already employed, there is need to introduce training, development programmes and use role models directed at improving vicarious learning. When hiring ARMS, banks can screen for social and networking abilities that facilitate the development and maintenance of long-term interpersonal relationship. This could be done via the relevant personal histories and through role-play situations during the interviewing process.

Another managerial implication relate to providing a conducive atmosphere that fosters lifelong learning by commercial banks. Creative ARMS continue to learn throughout their lives. More than half of the sampled respondents had undertaken full-time or part-time course, which 
they saw as enhancing their job prospects. In the banking industry, workers adapt, change direction and offer flexible services as required by the bank job rotation plan, aimed at building knowledge, flexibility and multiskilling. Some employees, aware of the changing nature of the banking industry and the apparent stiff competition, have resorted to sponsor themselves for continuing professional development. This study has revealed that some banks sponsor their employees for short and long-term training without providing a corresponding learning environment leading to failure and termination of their studies. Employers and employees should enter into a lifelong learning contract with clear terms and conditions for the parties involved. In-house training emphasizing vicarious learning and development network could be promoted. Salesforce training should include task and social disclosure and disclosure reciprocity at every stage of the selling process.

\section{LIMITATIONS OF THIS STUDY}

Although the results of this study are of interest to sales and marketing literature, this research has several shortcomings that limit interpretation of results. First, the sample is composed of only ARMS selling only to large account customers. Results of ARMS from other financial services sector like insurance, housing finance, micro-finance institutions may be quite different. This may be particularly true of firms selling both intangible (hotels, education and training, consultancy, religion) and tangible or technical products such as computer firms, scholastic products, manufacturing industry. The question of whether our findings generalize to other industries has not been addressed. The data presented here are cross sectional and salesforce performance cannot be concluded from this study, without conducting a longitudinal study. This study further adopted scales used by previous studies with differing cultural backgrounds. Future researchers might consider developing contextualized batteries commensurate with the banking culture in Uganda. It would also be logical to conduct a longitudinal study, using both qualitative and quantitative methodologies.

\section{AREAS FOR FUTURE RESEARCH}

Future research should extend the study to other service sectors of the economy like insurance, education, health sector, politics, religion and product-oriented companies, where personal selling is a vital function for their survival. There is a need to find out whether the results work with consumers than with more professional workers.

\section{REFERENCES}

Adler, P. and Kwon, S. (2002) Social capital: Prospects for a new concept. Academy of Management Review 27(1): 17-40.

Arthur, M. and Rousseau, D. (1996) The Boundaryless Career: A New Employment Principle for a New Organizational Era. New York, NY: Oxford University Press.

Bandura, A. (1972) Socialization. Lexikon der Psychologie, Band III. Freiburg im Breisgau: Herder.

Bandura, A. (1977) Self-efficacy: Towards a unifying theory of behavioural change. Psychological Review 84: 191-215. 
Bandura, A. (1986) Social Foundations of Thought and Action. Englewood Cliffs, NJ: Prentice Hall.

Bandura, A. (1997) Self-efficacy: The Exercise of Control. New York: Freeman.

Baum, J.A. and Paul, A.I. (1998) Survival enhancing learning in the Manhattan hotel industry, 1898-1980. Management Science 44(July): 996-1016.

Behrman, D.N. and Perreault Jr., W.D. (1982) Measuring the performance of industrial salespersons. Journal of Business Research 10: 335-370.

Betsworth, D.G. and Hansen, J-I.C. (1996) The categorisation of serendipitous career development events. Journal of Career Assessment 4: 91-98.

Chanley, V.A., Rudolph, T.A. and Rahn, W.M. (2000) The origins and consequences of public trust in government: A time series analysis. Public Opinion Quarterly 64(3): 239-256.

Churchill, G.A., Ford, N.M., Hartley, S.W and Walker, O.C. (1985) The determinants of sales force performance; a meta-analysis. Journal of Marketing Research 22(May): 103-118.

Cobbledick, S. (1996) The Information-seeking behaviour of artists: Explarotory interviews. Library Quarterly 66(4): 343-372.

Cory, K.A. (1999) Discovering hidden analogies in an online humanities database. Library Trends 48(1): 60-71.

Dexter, B.L. (1977) Special Education and the Classroom Teacher: Concepts, Perspectives, and Strategies. Springfield, IL: Thomas.

Diaz de Chumaceiro, C.L. (1995) Serendipity or pseudo serendipity? Unexpected versus desired results. Journal of Creative Behaviour 29: 143-146.

Ellen, P.S., Bearden, W.O. and Sharma, S. (1991) Resistance to technological innovations: An examination of the role of self-efficacy and performance satisfaction. Journal of the Academy of Marketing Science 19: 297-307.

Eyal, K. and Rubin, A.M. (2003) Viewer aggression and homophily: Identification, and parasocial relationships with television characters. Journal of Broadcasting and Electronic Media 47(1): 77-98.

Fontana, A. and Frey, J.H. (1998) Interviewing: The art of science. In: N.K. Denzin and Y.S. Lincoln (eds.) Collecting and Interpreting Qualitative Materials. Thousand Oaks, CA: Sage Publications, pp. 47-78.

Forret, M. and Dougherty, T. (2004) Networking behaviors and career outcomes: Differences for men and women. Journal of Organizational Behavior 25(3): 419-437.

Frechtling, J. and Sharp, L. (eds.) (1997) User-Friendly Handbook for Mixed Method Evaluations, Directorate for Education and Human Resources, Division of Research, Evaluation and Communication, National Science Foundation, Retrieved from the World Wide Web http://www.ehr.nsf.gov/EHR/REC/pubs/NSF97-153/START.HTM\#TOC, accessed 5 September 2001.

Gilligan, C. (1977) In a different voice: Women's conceptions of self and of morality. Harvard Educational Review 47(4): 481-517.

Gist, M.E. and Mitchell, T.R. (1992) Self-efficacy: A theoretical analysis of its determinants and malleability. Academy of Management Review 17: 183-211.

Goleman, D. (1998) Working with Emotional Intelligence. New York: Bantam.

Gordon, K.A. (1995) Self-concept and motivational patterns of resilient African-American high school students. Journal of Black Psychology 21(3): 239-255.

Higgins, M.C. and Kram, K.E. (2001) Reconceptualizing mentoring at work: A developmental network perspective. Academy of Management Review 26(2): 264-268.

Kakabadse, A. (1999) Younger does not mean better. The British Journal of Administrative Management (January/February): 9-11.

Kamuhanda, R.N. (2001) Managing change in Ugandan Commercial Banking Organisations. A Dissertation submitted to Makerere University for an MBA award.

Kathleen, E.M., Levin, A.S. and Krumboltz, J.D. (1999) Planned happenstance: Constructing unexpected career opportunities. Journal of Counselling and Development 77(2): $115-124$.

Kelly, G.A. (1955) The Psychology of Personal Constructs, Vol. 2, New York, NY: Norton.

Kelly, G.A. (1973) The psychology of personal constructs. In: J. Rychlak (ed.) Introduction to Personality and Psychotherapy. Boston, MA: Houghton Mifflin.

King, A.S., Ehrhard, A.S. and Parks, C. (1998) The crescendo effect in career motivation: An eight phase model. International Journal of Management 15(3): 302-312.

Kirk, J. and Miller, M.L. (1986) Reliability and Validity in Qualitative Research. Beverly Hills, CA: Sage Publications.

LeCompte, M.D. and Goetz, J.P. (1982) Problems of reliability and validity in ethnographic research. Review of Educational Research 52(1): 31-60.

Lent, R.W., Hackett, G. and Brown, S.D. (1996) A social cognitive framework for studying career choice and transition to work. Journal of Vocational Education Research 21(4): 3-31. 
Leong, S.M., Busch, P.S. and Roedder, J.D. (1990) Knowledge bases and salesperson effectiveness: A script theoretic analysis. Journal of Marketing Research 26(2): 53-63.

Lumpkin, G.T. and Dess, G.G. (1996) Clarifying the entrepreneurial orientation construct and linking it to performance. Academy of Management Review 12(1): 135-172.

Marakas, G.M. (1998) Decision Support Systems in the Twenty-First Century. Upper Saddle River, NJ: Prentice Hall.

Molloy, J.C. (2005) Development networks: Literature review and future research. Career Development International 10(6/7): 536-547.

Miles, M.B. and Huberman, A.M. (1994) Qualitative Data Analysis. Beverly Hills, CA: Sage.

Montgomery, B.M. (1993) Relationship maintenance versus relationship change: A dialectical dilemma. Journal of Social and Personal Relationships 10(2): 205-223.

Newman, I. and Benz, C.R. (1998) Qualitative-Quantitative Research Methodology - Exploring the Interactive Continuum. Carbondale, IL: Southern Illinois University Press, pp. 9, 65-67.

Ntayi, J.M. (2005) Career resilience and salesforce performance. PhD thesis.

Plank, R.E. and Reid, D.A. (1994) The mediating role of sales behaviours: And alternative perspective of sales performance and effectiveness. Journal of Personal Selling and Sales Management 14(Summer): 43-56.

Remer, T.G. (1965) Serendipity and the Three Princes. Norman, OK: University of Oklahoma Press.

Rosenblatt, P.C., de Mik, L., Anderson, R.M. and Johnson, P.A. (1985) The Family Business. San Francisco: Jossey-Bass.

Rotter, J. (1966) Generalized expectancies for internal versus external control of reinforcement. Psychological Monographs 80(1): 609.

Schwarzer, R. (1994) Optimism, vulnerability and self-beliefs as heath-related cognitions: A systematic overview. Psychology and Health 9: 161-180.

Schneider, B. (1994) HRM: A service perspective - Toward a customer-focused HRM. International Journal of Service Industry Management 5: 64-76.

Shaw, M.E. (1981) Group Dynamics: The Psychology of Small Group Behaviour. New York: McGraw Hill.

Shaw, J.D., Delery, J.E., Jenkins, G.D., Jr., and Gupta, N. (1998) An Organization-level analysis of voluntary and involuntary turnover. Academy of Management Journal 41(5): 511-525.

Spiro, R.L. and Weitz, B.A. (1990) Adaptive selling: Conceptualization, measurement, and nomological validity. Journal of Marketing Research 27(February): 61-69.

Stewart, K. (1998) The customer exit process - A review and research agenda. Journal of Marketing Management 14(4): 235-250.

Strauss, A. and Corbin, J. (1990) Basics of Qualitative Research: Grounded Theory Procedures and Techniques. London: SAGE Publications.

Sujan, H., Sujan, M. and Bettman, J. (1988) Knowledge structure differences between more effective and less effective salespeople. Journal of Marketing Research 25(February): 81-86.

Swinney, D., Love, T., Nicol, J., Bouck, V. and Hald, L.A. (2000) Neuroanatomical organization of sentential processing operations: Evidence from aphasia on the (modular) processing of discontinuous dependencies (Chapter 3). In: R. Bastiannse and Y. Grodzinsky (eds.) Grammatical Disorders in Aphasia: A Neurolinguistic Perspective. London: Whurr Publishers, pp. 51-66.

Szymanski, D.M. and Churchill, G.A. (1990) Client evaluation cues: A comparison of successful and unsuccessful sales people. Journal of Marketing Research 27(2): 163-174.

Tashakkori, A. and Teddlie, Ch. (1998) Mixed Methods: Combining Qualitative and Quantitative Approaches. Thousand Oaks, CA: Sage Publications.

Weitz, B., Sujan, H. and Sujan, M. (1986, October) Knowledge, motivation and adaptive behavior: A framework for improving selling effectiveness. Journal of Marketing 50: 174-191.

Wiseman, R. (2003) Hidden world of bullying. Safe schools project, http://www.odedodea.edu/ dodsafeschools/members/dailyupdates/2003-January.html, accessed July 2004

Zeldin, A.L. and Pajares, F. (2000) Against the odds: Self-efficacy beliefs of women in mathematical, scientific, and technological careers. American Educational Research Journal 37: $215-246$. 